\title{
Philip Jacob White, M.B.
}

Philip JACOB White, though he first saw the light in India, came of good old Aberdeenshire stock. He was born in 1863 at Purandhar in the Bombay Presidency, his father being the Rev. Adam White, a pioneer of mission work in India. He received his education mainly in Edinburgh, first at Fettes College and afterwards at the University. In 1887 he graduated in Medicine, gaining distinction in many of his classes and being a prizernan in Zoology. Soon after graduating he was appointed assistant in the Natural History Department of the University of Edinburgh. This department had been undergoing reorganisation and development, and White's keenness for the subject was especially helpful in carrying on the recently established courses in Practical Zoology. This experience proved of great value to him when in 1889 he was appointed lecturer in Zoology at University College, Bangor, N. Wales. Here he had everything to do, and he threw himself heart and soul into the task of developing his department.

His efforts were so successful that after seven years, in 1896, the lectureship was made into a Professorship of Zoology. He regarded the establishment of a museum as of first-class importance-it may be said it was one of his cherished ideals-and he grudged neither time nor trouble to obtain specimens. His knowledge of comparative anatomy, together with his rare judgment of the value of specimens, stood him in good stead, and in course of time he created a museum which enabled the Natural History students of Bangor to acquire a thorough knowledge of their subject.

His activities were, however, not confined to his own class-room. $\mathrm{He}$ did much for the University Extension Movement, lecturing in many. of the towns and villages of $\mathrm{N}$. Wales, and in 1895 he instituted a course in Agricultural Zoology-a pioneer step. He was also deeply interested in Marine Zoology. For some thirty years he was a member of the Lancashire and Western Sea Fisheries Committee, and he rendered conspicuous service in connection with the Conway Mussel and Sparling Fishery. In 1890 he was appointed Director of the Biological Station on Puffin Island, founded by Professor Herdman, which had been taken over by the Zoological Department of the University College of N. Wales, and 
did useful work in an investigation of the land and sea fauna of the island, and in co-ordinating the results of research of other workers.

He was elected a Fellow of the Royal Society of Edinburgh in 1896. One of his papers, "The Existence of Skeletal Elements between Mandibular and Hyoid Arches in Hexanchus and Læmargus," was published in the Transactions of the Society in 1889, and this paper also appeared in the Anatomischer Anzeiger in 1895.

He was a member of the Court of Governors of the National Museum of Wales.

As a man he had a delightful personality. His intense keenness and enthusiasm were contagious, and fired those who came in contact with him, particularly his students, in all of whom he took a personal interest. Many of them will feel his loss irreparable.

He died on 26th December 1929. 